\title{
Problems and Countermeasures in Moral Education of Counselors in Southwest Petroleum University
}

\author{
Shulei Song \\ College of Chemistry and Chemical Engineering, Southwest Petroleum University, Chengdu, China \\ Email: Songshulei2019@163.com
}

How to cite this paper: Song, S. L. (2019). Problems and Countermeasures in Moral Education of Counselors in Southwest Petroleum University. Creative Education, 10, 1357-1364.

https://doi.org/10.4236/ce.2019.107101

Received: June 13, 2019

Accepted: July 3, 2019

Published: July 5, 2019

Copyright $\odot 2019$ by author(s) and Scientific Research Publishing Inc. This work is licensed under the Creative Commons Attribution International License (CC BY 4.0).

http://creativecommons.org/licenses/by/4.0/

\section{(c) (i) Open Access}

\begin{abstract}
With the deepening of higher education reform, the teaching staff of counselors in Southwest Petroleum University plays an increasingly important role in the moral education of College students, and the society and schools are increasingly demanding counselors. The effect of College counselors' moral education will directly affect the quality of school personnel training. But through the research, we find that there are some problems in the moral education of College counselors. We try to analyze these problems and the reasons behind them, and actively explore the corresponding countermeasures, the fundamental path to promote the moral education of College counselors, and the proper choice to further enrich and develop the moral education theory of College counselors and broaden the vision of Cultivating College Students' moral qualities, and conform to the necessity of professionalization of College counselors at the same time.
\end{abstract}

\section{Keywords}

Moral Education, Ideological Education, Counselors, Southwest Petroleum University

\section{Introduction}

In October 2004, the State Council of the CPC Central Committee issued the Opinions on Further Strengthening and Improving the Ideological and Political Education of College Students, which clearly pointed out that "the work force of Ideological and political education is the organizational guarantee for strengthening and improving the ideological and political education of College students". The main body of the ideological and political education work force of 
college students is the school party and government cadres and the Communist Youth League cadres, teachers of Ideological and political theory courses and philosophy and Social Sciences courses, counselors and head teachers. At the same time, it emphasizes that "counselors and head teachers are the backbone of Ideological and political education for college students." In 2005, the Ministry of Education promulgated "Opinions on Strengthening the Construction of College Counselors' Team of Head Teachers", pointing out that "Counselors and Head Teachers are an important part of the Teachers' Team of Colleges and Universities, the backbone of moral education in Colleges and universities, the backbone of Ideological and political education for college students, and the guide and guide of healthy growth of College students".

Without exception, these documents convey to us the spirit that it is incumbent upon counselors to pay full attention to the status and role of counselors in the moral education of college students and promote their healthy growth. In its report to UNESCO, the International Commission on Education for the 21st Century, chaired by Jacques Delor, pointed out that: "In fact, every member of society should take responsibility for others every day in his career, culture, association and consumption activities. Therefore, schools should be prepared for everyone to play this role" (Schemrich, 2003).

In the new era and new situation, new challenges and requirements are put forward for the work of counselors, especially for how to better carry out moral education for college students. Some scholars believe that "after the reform and opening up, more and more college students have only one child. Their consciousness of self-determination, innovation and success has become more conscious and has a broader vision. But at the same time, to varying degrees, there are also weak political beliefs, confused ideals and beliefs, indifferent sense of integrity, lack of social responsibility, prominent individualism and weak spirit of arduous struggle." How to make counselors grasp the key points in the moral education work in peacetime, solve the puzzles faced by college students in such fields as professional ethics, social ethics, marriage and family ethics, and ensure that students can have a correct moral outlook, and put it into the correct moral action. It is one of the urgent problems to be solved in the construction of counselors' team at this stage.

\section{Problems Existing in Current Counselors' Moral Education}

1) The construction of moral education idea and reality

Constructing scientific moral education concept is the premise to improve the epochality, pertinence and effectiveness of moral education in schools. First, some colleges and universities advocate the unscientific concept of moral education. Some colleges and universities have only slogans and slogans of moral education, which have a beautiful appearance of "being tall and above the world". Moral education is positioned in an idealized realm (such as a university: perfect human nature; inheriting the Chinese tradition, embracing the civiliza- 
tion of the four seas). It is not close to school conditions and academic sentiments, and lacks vivid elements of the times (Kohlberg, 1984). Secondly, some moral education concepts in Colleges and universities are difficult to implement. "Difficulty" exists in the school's main leadership ideology such as "moral education is important to say, not to be busy" and other erroneous understandings, leading to slow action or no promotion measures; "Difficulty" has no grasp, cannot find a suitable breakthrough in the practice of moral education concepts, supporting measures; "Difficulty" in some teachers' ignorance of the school's moral education concepts, because the right to interpret moral education concepts is in the minority. In the minds of those who formulate moral education, the recognition of moral education concept is low, which leads to some teachers' ideological indifference, emotional resistance and action neglect.

2) The construction of moral education system lags behind

Under the new situation, schools need scientific and reasonable moral education system to regulate students, to improve the construction of moral education system, and to cultivate students' respect for moral education system and moral education viewpoints. At present, the construction of moral education system in Colleges and universities mainly has the following problems: First, the moral education system is not perfect. Some colleges and universities are arbitrary in the formulation of moral education system, failing to plan from the overall level of moral education in schools, lacking comprehensiveness, integrity and continuity. Secondly, the moral education system is set up. Many institutions in some colleges and universities are often put on the shelf, failing to effectively play their due role in regulating, restricting and promoting moral education in schools; or only formulating systems, but missing key links such as implementation, supervision, assessment, feedback and rectification, leading to the implementation of moral education system is not in place. Third, the renewal of moral education system is slow. The moral education system in some universities is out of date, unable to match the requirements of moral education in the new era, with poor timeliness. It failed to scientifically demonstrate the rationality and feasibility of the existence of the content of moral education system, and failed to "discard the dross and extract its essence" (Kohlberg \& Turiel, 1971).

3) The construction of moral education team needs to be strengthened

School moral education team plays an important role in personnel training. With the expansion of College enrollment, the number of students is increasing, but the growth rate of counselors has not kept pace with the expansion of student size, resulting in the relative lack of the number and quality of full-time moral education team. First, the structure of moral education team is unreasonable. Some colleges and universities have not matched the full-time and part-time moral education institutions and personnel according to the requirements, and the number of full-time and part-time moral education staff is too small. Second, the overall quality of moral education team is not high. Under the new situation, impacted by various ideological trends in society, some moral educators' thoughts have changed greatly. They lack the sense of education, de- 
dication, dedication and responsibility. They have no intention to teach and reform (Smith, 1978). They cannot organically combine the current moral education work in schools with the new situations and problems that arise at present, and it is difficult to solve the puzzles of students. Third, the moral education team is unstable. Due to the lack of implementation in the evaluation of promotion and welfare treatment, the phenomenon of moral education staff turnover occurs from time to time.

4) The evaluation method of moral education is unitary and has poor maneuverability

Moral education evaluation is an important way to judge the efficiency and social effect of moral education in schools, an important link in the whole moral education process, and also one of the main contents of moral education. At present, the following tendencies of moral education evaluation in Colleges and universities deserve attention. Firstly, we should re-evaluate and lighten the quantitative evaluation. For a long time, moral education evaluation in many colleges and universities is characterized by qualitative evaluation (Wang, 2009), but neglects quantitative evaluation. Qualitative evaluation is based on impression and experience. It often fails to grasp the characteristics and essence of the evaluation object's moral status, to accurately summarize the moral differences among students, which easily leads to subjectivity and arbitrariness of moral education evaluation, and leads to partial generalization, point-to-point and surface-to-face, and fails to draw correct evaluation conclusions. Secondly, static evaluation is emphasized, while dynamic evaluation is neglected. Many colleges and universities pay more attention to the evaluation of the results of moral education, often regard moral education evaluation as the "terminator" of moral education in schools, and measure the moral education status of schools and students' ideological and moral status from the existing achievements. However, they pay less attention to the evaluation of moral education process and lack of dynamic examination of students' moral development. Thirdly, we should pay more attention to abstract evaluation than concrete evaluation. At present, the objectives of moral education in Colleges and universities are often too abstract, empty and unified, and there is a lack of appropriate hierarchy between the objectives and objectives, which is not in line with the actual situation of students and school moral education. It is difficult to reflect the characteristics of moral education in schools and students' ideological and moral character, which is more abstract and less specific.

\section{Research on the Countermeasure of Promoting the Moral Education of College Counselors}

1) Perfecting the working mechanism of college counselors

Nowadays, our country only has three national documents which are directly related to counselors and focus on solving policy problems. However, there is no authoritative consensus on the profession and nature of counselors in the whole society, and it has not reached the level of widespread understanding and recog- 
nition of such professions as civil servants, soldiers, doctors, lawyers and police. The professional development of college counselor team depends on the development of counselor team system. The process of counselor specialization construction is the process of constructing a stable and sustainable system adapted to the counselor team.

At present, most of the counselors in Colleges and universities in our country are full-time and part-time. Some of them are non-professional, some are part-time graduate students, and some are half-way to change careers. The focus of the professionalization of the counselors is to make the part-time team professional and improve the industry standards. By integrating the work resources of counselors, improving the training mechanism of counselors and improving the evaluation mechanism of counselors (Newton, 1978).

The continuous improvement of the working mechanism of counselors is not only the fundamental way to maintain the stability of counselors, but also the inevitable choice to ensure the comprehensive and sustainable development of College Students' moral education. Only in this way can counselors truly become "guiders of students' ideological and moral education, enlightenments to guide students' independent learning and exploration, servers to improve students' moral education quality, nurturers to promote students' physical and mental health, and helpers to enhance students' survival ability".

2) Scientific top-level design idea of moral education

The idea of moral education is the guide to carry out moral education in schools. First, we need to be contemporary. At present, college students lack recognition of the moral concept of individual or group-oriented advocated by moral education in Colleges and universities. There are internal and external conflicts, inconsistencies in words and deeds, and even moral hypocrisy in morality. If we want to change this situation, we must reshape the rational moral education idea which embodies the spirit of the times. Modern moral education concept should focus on people and their lives, emphasize people-oriented spirit and advocate moral education close to life. This idea of moral education is based on society, which correctly solves the problem of the relationship between individual and society as a whole. Only this kind of morality can be accepted and internalized consciously and voluntarily by college students, so as to improve their moral quality. Second, we need to be grounding gas. The top-level design of moral education idea can embody the excellent historical elements accumulated by the school itself for a long time, the unique elements of vocational education itself, and the elements of life moral education that conform to the law of students' moral cognitive development. After the establishment of this concept of moral education, we should strengthen the propaganda and education of public opinion for teachers and students in the whole school, guide the moral education work of the whole school, and permeate the whole process of moral education work in the school.

3) Establishing and perfecting moral education system

Moral education system is the guarantee of moral education in schools. One is 
to clarify the existing system. A large number of moral education systems in schools have been inherited for a long time, and some of them even belong to local methods, which are in contradiction with new moral education ideas and laws. Schools should sort out, examine and analyze the existing moral education system (including written and unwritten systems, some "effective" habits and practices), retain and improve the reasonable factors, and remove and reform the unreasonable content. Second, we should improve the moral education system. Moral education system includes basic system, implementation system and supervision system. The basic system is a system to guarantee the status of moral education in the overall work of schools. The implementation system is a system to carry out moral education in schools according to modern moral education concepts. The supervision system is a system arrangement to ensure the effective operation of the basic system and the implementation system. How to ensure that the supervisory system can effectively exercise its supervisory function is not only the key to the implementation of moral education reform in schools, but also the most difficult part in the design and construction of moral education system. Thirdly, the relevant system should be updated regularly. The purpose of doing so is to make the school moral education system conform to the needs of moral education and the law of moral education, to the social requirements of the times, and to the needs of students' growth (Yang, 2007).

4) Promoting the construction of moral education team

In a sense, the level of moral education in schools depends on the level of moral education team construction. We should strive to build a team of moral education in Colleges and universities with appropriate quantity, reasonable structure, excellent quality, deep theoretical foundation and love of moral education. First, we should pay attention to expanding the capacity and quality of moral education team. When choosing moral education staff, we should focus on the number of departments, age structure, knowledge structure and professional structure ( $\mathrm{Li}, 2008)$. We should also consider the combination of division of labor, full-time and part-time jobs, and make a reasonable match so as to optimize the overall structure and improve the overall quality. Second, we should pay attention to strengthening the professional and professional construction of moral education team. For example, on the basis of strengthening the professional ideal education of moral education staff, perfecting the norms of teachers' ethics, perfecting the incentive mechanism, perfecting the supervisory mechanism of teachers' ethics, and strict assessment and management, strengthening the construction of teachers' moral education training bases and famous class teachers' studios, perfecting the incentive mechanism of class teachers' training, gradually forming a new, on-the-job and backbone class teachers' echelon training mode, and improving the team of class teachers, professional level, etc. Third, we should pay attention to the integration of social education forces. Colleges and universities should give full play to the functions of the school moral education work committee and carry out activities regularly, and encourage advanced figures such as professions, enterprise labor models, technical experts 
and outstanding graduates to act as "part-time moral education counselors" for students and actively carry out activities (Kohlberg, 1987).

5) Emphasizing the innovation of moral education evaluation means

Scientific moral education evaluation can not only provide the basis for the establishment of moral education objectives, the correct selection and application of moral education contents and methods, but also externalize the effect and value of moral education. First, both qualitative and quantitative evaluation should be combined. We should not only see the advantages of qualitative analysis, but also the shortcomings of quantitative analysis. Good qualitative evaluation can achieve three-point effect, accurately grasp the essence of the evaluation object's moral status; bad quantitative evaluation is not conducive to moral education work in schools, but to "science" to decorate the facade, so that people do not know what to do. Second, we should lay equal stress on the combination of results evaluation and process evaluation. We should not only see the results of moral education, but also pay attention to the dynamic point of view. We should see the development of students' ideological and moral character and the potential of moral education in schools. We should not only see the existing performance of students and schools, but also promote the development of students' ideological and moral character and the improvement of moral education in schools through evaluation. Third, avoid the hollowness of moral education evaluation (Vygotsky, 1997). Under the new historical conditions, the goal of moral education should be based on reality, close to reality and higher than reality. We should not only attach importance to the ideal orientation of moral education evaluation, but also attach importance to the Realistic Orientation of moral education evaluation, enrich the evaluation goal with the spirit of the times, and avoid the hollowness of moral education evaluation.

\section{Conclusion}

Adhering to the principle of "educating people first and moral education first" is the direction of the moral education work of counselors in Southwest Petroleum University. It is also the primary duty of counselors' moral education work in Southwest Petroleum University to firmly grasp the fundamental task of cultivating people through moral education, further strengthen and improve the moral education work of counselors in Southwest Petroleum University, and effectively integrate socialist core values into the whole process of school moral education. At present, the moral education of Southwest Petroleum University has made some achievements, and the ideological concept of "educating people first and moral education first" has basically taken shape. The correct world outlook, outlook on life, values and socialist outlook on honor and disgrace have been further established. However, we should also realize clearly that there is still a gap between the current moral education and the requirements of building a harmonious society, and a lot of moral education. To a large extent, it follows the traditional way and does not make corresponding adjustments in time. Moral education even tends to be marginalized. It is a long way to go to establish a 
situation of full-staff, all-round and whole-process education. Therefore, this paper studies and analyses the problems existing in the moral education of counselors in Southwest Petroleum University, and studies the countermeasures, so as to better improve and promote the moral education of counselors in Southwest Petroleum University.

\section{Conflicts of Interest}

The authors declare no conflicts of interest regarding the publication of this paper.

\section{References}

Kohlberg, L. (1984). Psychology of Moral Development. Shanghai: Huadong Normal University Press.

Kohlberg, L. (1987). Philosophy of Moral Education. Hangzhou: Zhejiang Education Press.

Kohlberg, L., \& Turiel, E. (1971). Moral Development and Moral Education. In L. Kohlberg (Ed.), Collected Papers on Moral Development and Moral Education (pp. 410-465). Moral Education \& Research Foundation. https://doi.org/10.3138/9781442656758-004

Li, Z. T. (2008). Inspiration of Kohlberg's Theory of Moral Development to Moral Education in China. Zhongtian Journal, 138-140.

Newton, R. R. (1978). Kohlberg: Implications for High School Programs. Living Light, 15, 231-239.

Schemrich, C. M. (2003). Applying Principles of Kohlberg's Theory of Moral Development to Classroom Instruction, Classroom Discipline Procedures, School-Wide Discipline Procedures, District Programs and Community Programs. Master's Thesis, Akron, $\mathrm{OH}$ : University of Akron.

Smith, A. F. (1978). Lawrence Kohlberg's Cognitive Stage Theory of the Development of Moral Judgment. New Directions for Students Service, 1978, 53-67. https://doi.org/10.1002/ss.37119780406

Vygotsky, L. S. (1997). Interaction between Learning and Development. In M. Gauvain, \& G. M. Cole (Eds.), Readings on the Development of Children (2nd ed., pp. 29-36). New York: W. H. Freeman.

Wang, X. F. (2009). Inspiration of Kohlberg's “Regression Theory” on Moral Education. Studies Monthly, No. 5, 27-28.

Yang, S. G. (2007). New Development of Moral Psychology in the West. Shanghai: Shanghai Education Press. 